\title{
Analysis of Speech Function and Mood System \\ of WhatsApp's Terms of Service
}

\author{
Mohammad Muhyidin \\ muhyidinmoh@gmail.com
}

\begin{abstract}
This study is aimed to find out the kinds of speech function realizations in whatsapp's terms of service and to find out mood types in each clause in whatsApp's terms of service. It is analyzed through identification of clauses Mood structures then being classified into four kinds of speech function; Statement, Question, Command and Offer.

There are two kinds of clauses. They are 186 clauses of Terms of Service and 150 clauses of Privacy Notices. The mood types found in the text are 139 declarative clauses and 23 imperative clauses on text of Terms of Service. There are 123 clauses of declarative and 18 imperative clauses on the text of Privacy Notices. There are 262 declarative clauses in text, 41 imperative clauses. It means that declarative clauses are the most dominant in the text. The speech functions found are $262(86,46 \%)$ statements \{divided in 139 in Terms of service and 123 in privacy notices\}, command is 41 (13, $53 \%$ ) divided in 23 in the Terms of service and 18 privacy notices.

It can be concluded that the Terms of service and privacy notices are giving information and ask the reader to do something to the users of WhatApps's applications. WhatApp's Terms of Service were dominated by declarative as mood types and all of them used statements as speech functions. Privacy Notices were dominated by declarative as mood types and statements as speech functions. It means that WhatsApp's Terms of Service mostly give information than demand service and privacy notices mostly give the information and contains of demand of users.
\end{abstract}

Keywords: Speech functions, mood types. 


\section{Introduction}

Spoken and written languages are both complex but in different ways. Spoken language tends to be complex grammatically and written language tends to be complex lexically. Spoken language tends to be grammatically intricate whereas written language tends to be lexically dense (Gerot \& Wignell, 1994).

"The fundamental components meaning in language are functional components. All languages are organized around three main kinds of meanings such as ideational meanings, interpersonal meanings and textual meanings" (Halliday, 1985, p.13). Those important components of meanings or metafunctions are added in the structure of clauses.

One of the most popular electronic networks use to communicate is WhatsApp. There are some facilities for user, such as; sharing the ideas or sending messages in WhatsApp; service of following other users; and access to see other user's messages.

Textual meanings express the relation of language to its environment, including both the verbal environment - what has been said or written before (co-text) and the non-verbal, situational environment (context). These meanings are realized through patterns of Theme and Cohesion. Textual meanings are most centrally influenced by mode of discourse. In this study, the data is "WhatsApp terms of service", which is in the written text form. The data is the terms of service, which consists of services and privacy notices. Based on the three kinds of meanings explained above, the researcher decided to analyze interpersonal meaning. 
The researcher chooses this data which is WhatsApp terms of service because it is one of the most popular social networks in this time. The main requirements need to access all of the terms of services. Users also need to agree with all of the terms in WhatsApp related to the use of the service. It becomes the main part of WhatsApp's service and contains of written texts that have spoken meaning. At the same time, a text is a series of exchanges between speaker and addressee even if it is a one-side monologue that is essentially a series of statement acknowledged silently by the addressee.

Those are the reasons to conduct this research on mood system and speech functions on WhatsApp Term of services.

\section{Literature Review}

Mood

Halliday (1985) state that language is a system of meanings. Halliday also believes that grammar is semantic (meaning) and functional (how the language is used). Based on this opinion, we know that the grammar becomes a study of how meaning built up with words and other linguistics forms. When people use languages, their language acts are the expression of meaning. 


\section{Mood Types}

Halliday and Matthiesen (2004) state there are two major types of mood, indicative mood and imperative mood. The indicative itself consist of declarative, interrogative, imperative and exclamative.

Yeibo (2011) states that, the sentence can be used to approve or disapprove, to express doubt, to ask questions or give answers; to greet, instruct, or to command others. These various uses or functions of the sentence correspond to grammatical categories which are called declarative (statement sentence): imperative (commands,requests) and exclamatory (exclamative).

"Mood in English is realized by the position in the clause of the subject and finite" (Gerot \& Wignell, 1994, p.38). Mood is divided into two types; there are indicative mood and imperative mood. Indicative mood can also be subdivided into two kinds, there are declarative mood and interrogative mood, and interrogative mood is also two kinds, that are polar (yes/no question) and Wh- questions. Types of mood are realized in the diagram:

\section{Figure 1 Mood Type}

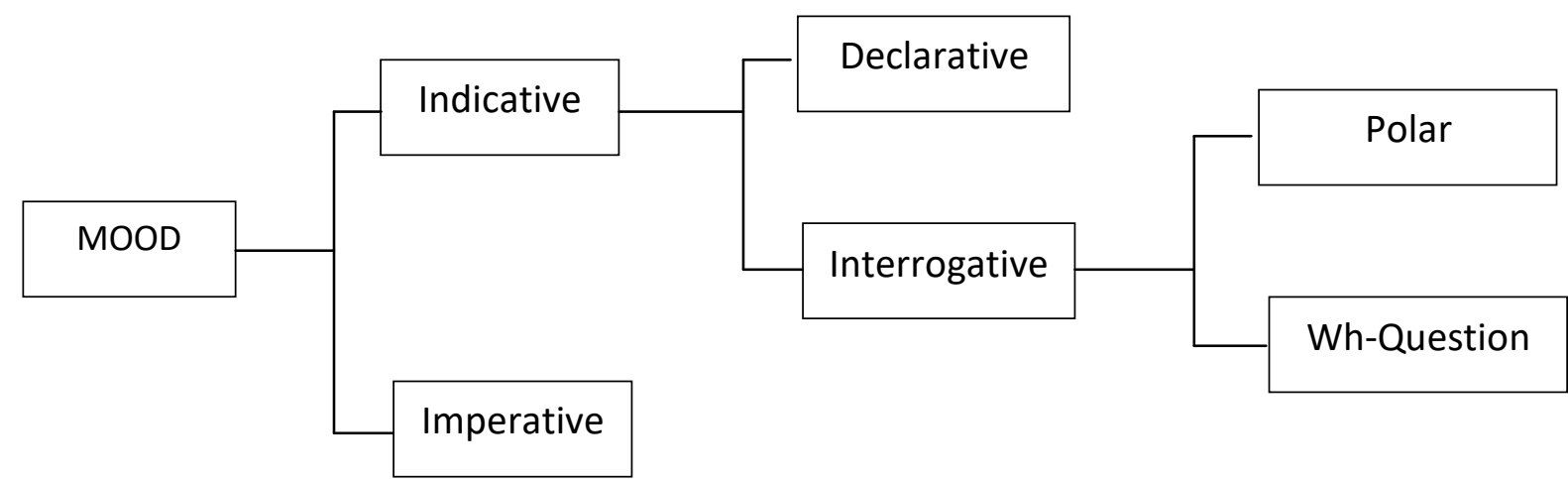




\section{Speech function}

Halliday (1994) states cutting across this basic distinction between giving and demanding is another distinction, equally fundamental, that relates to the nature of the commodity being exchanged. This may be either (a) goods and services or (b) information.

Speech functions categories have been identified, often arising from the particular interests of a researcher or the focus of a particular study. Halliday (1994) identifies a function of language concerned with learning, which he labels as heuristic, and glosses as the 'tell me why' functions. Gerot and Wignell (1994) state there are options of speech functions:

\section{Offer}

The speaker gives the hearer some goods or services and the speaker inherently invites the hearer to receive those goods and services. Example: Would you mind opening the window?

\section{Command}

The speaker demands the hearer some goods and services and the hearer are thereby invited to give that service or provide the goods. Example: "see the notification tab of setting for more".

\section{Statement}

The speaker gives the hearer some information and the speaker inherently is inviting the hearer to receive that information. Example: "the 
types and extent of advertising by WhatsApp on the services are subject to change".

\section{Question}

The speaker demands the hearer some information and the speaker inherently is inviting the hearer to give that information. Example: "do you agree about this term?"

The data gathering in this present study will be executed by adapting and reviewing for the following study:

1. Azkiya \& Arina. (2013). Speech Function Analysis of Teacher-Student Interaction in an Immersion Class at Virginia Tech Language and Culture Institute. Department Of English Education Faculty of Teacher Training and Education University of Muria Kudus.

"In interacting with one another, we enter into arrange of interpersonal relationships, choosing among semantic strategies such as cajoling, persuading, enticing, requesting, ordering, suggesting, asserting, insisting, doubting, and so on. The grammar provides us with the basic resource for expressing these speech functions, in the form of a highly generalized set of clause system referred to as Mood. This research is aimed to find out the mood types and speech functions found in an immersion class activity at Virginia Tech Language and Culture Institute which was held on November 2011. Using systematic-Functional Grammar, it was analyzed through identification of clause Mood structures then 
being classified into four kinds of speech function; Statement, Question, Command and Offer.”

2. Rosida, W. (2015). "The Analysis of Speech functions through the dialogue in braveheart movie script", Research, Tarbiyah, English Department, The State College for Islamic Studies of Kediri

"Sociolinguistic has the function in giving knowledge about how to use the language, to which you speak, and what you talk or communicate. Speech function is human communication instrument, written or oral. Janet Holmes divides speech function in to six parts. They are expressive utterance, directive utterance, referential utterance, metalinguistic utterance, phatic utterance, and poetic utterance. The objective of this study describes kind of speech function through the dialogue in brave heart movie script. It also shows the relation of speech function to social life of Scotland in brave heart movie script."

3. Fauzia, S. (2013)." Mood and Speech Function Realization in the WhatsApp's Terms of Service", Faculty of Humanities, Dian Nuswantoro University, Semarang.

"Rights of terms were dominated by declaratives as the mood types and all of them used statements as the speech function. Moreover, Responsibilities were dominated by declaratives as the mood types and statements as the speech function and contains imperatives as the mood types and command as the speech function. It means that in "WhatsApp's terms of Rights" mostly give the 
information than demand service and Responsibilities even though mostly give the information and contains of demands goods or services.

\section{Method}

In this research, there are two instruments used to get the data from the subject of the study. They are consisting of the researcher herself, documentation, observation. This research used documentation method because the researcher collected the data from the text of terms of service in Research. The data of the study were collected in the following steps, They are Searching the terms of service of WhatsApp on the website https://WhatsApp.com. In this stage, the researcher searched the data refer to the topic of the study from the internet, collecting the text of WhatsApp's Terms of Service and Privacy Notices. In this stage, the researcher downloaded the Terms of service for the analysis, analyzing mood types. After getting the data, the researcher analyzes the clauses into mood types categories and analyzing speech functions.

Miles and Huberman (1984) state there are some procedures to analyze the data in Qualitative Research; data reduction, data display and conclusion or verification. After the data of the research had been collected, they were analyzed by using following steps, they are reading the clauses in "WhatsApp's terms of service", segmenting the clauses, identifying mood types and speech functions in every clause found in the WhatsApp's terms of service, classifying the mood types and speech functions in every clause found in the WhatsApp's terms of service", interpreting the data and drawing 
conclusion. Drawing and Verifying Conclusion. At the end of the study, the researcher made conclusion based on the problem has been analyzed.

\section{Results and Discussion}

Reading the terms of service is done to get the idea for analyzing the data. It segmented into rights and responsibilities, then into clauses to make the analysis done easily. This study applying mood types and speech function refer to the theories by Halliday (1994), and Gerot and Wignell (1994).

\section{Finding of Mood Types and Speech Functions in WhatsApp Terms of Services}

The researcher found 336 clauses. The clauses are divided into 186 clauses on WhatsApp's Terms and Service and 150 clauses found in WhatsApp's Privacy Notices. Below are the details of all the analysis in this research.

\section{Table 1}

Frequency of clauses in the text of Research Terms of Service

\begin{tabular}{|c|c|c|}
\hline \multirow{2}{*}{ Parties } & \multicolumn{2}{|c|}{ Clauses } \\
\cline { 2 - 3 } & Freq. & \% \\
\hline Terms of Services & 186 & $55.35 \%$ \\
\hline Privacy Notices & 150 & $44.64 \%$ \\
\hline Total & $\mathbf{3 3 6}$ & $\mathbf{1 0 0 \%}$ \\
\hline
\end{tabular}


It can be seen that the frequency of the clauses found in the text are 332 clauses. The clauses of WhatsApp's Terms of Service are $186(55.35 \%)$ is major than the clauses of Privacy Notices $150(44.64 \%)$ found in the text.

The clauses which are the main analysis in this research are categorized into five types of clauses. They are declarative clause, interrogative clause, imperative clause, negative clauses and exclamative clause. The researcher found declarative clauses 262 clauses, 0 interrogative clauses, 41 imperative clauses, 33 negative clauses and 0 exclamative clauses. The data of the research is in the appendixes.

\section{Mood Types}

The mood types on the text are categorized into four types of clauses, they are declarative, interrogative, imperative and exclamative. In this study, the researcher only fount two types of mood, they are declarative and imperative. It can be seen from the frequency of mood system and shown in the table below:

Table 2

The Frequency of Mood Types found in the WhatsApp's Terms of Service

\begin{tabular}{|c|l|c|c|c|c|c|}
\hline \multirow{2}{*}{ Parties } & \multicolumn{6}{|c|}{ Mood types } \\
\cline { 2 - 7 } & \multicolumn{2}{|c|}{ Declarative } & \multicolumn{2}{c|}{ Imperative } & \multicolumn{2}{c|}{ Total } \\
\hline & Freq. & $\mathbf{\%}$ & Freq. & $\%$ & Freq. & $\%$ \\
\hline Terms of Service & 139 & $45.87 \%$ & 23 & $7.59 \%$ & 162 & $53.46 \%$ \\
\hline Privacy Notices & 123 & $40.59 \%$ & 18 & $5.94 \%$ & 141 & $46.53 \%$ \\
\hline Total & $\mathbf{2 6 2}$ & $\mathbf{8 6 . 4 6 \%}$ & $\mathbf{4 1}$ & $\mathbf{1 3 . 5 3 \%}$ & $\mathbf{3 0 3}$ & $\mathbf{1 0 0 \%}$ \\
\hline
\end{tabular}

From the table 2 above, it can be seen that there are two types of mood in the text of WhatsApp's terms of service and privacy notice. They are declarative mood 
type, imperative mood type. In the table, there are 262 declarative clauses in text, 41 imperative clauses. It means that declarative clauses are the most dominant in the text. The mood types are discussed below:

\section{Declarative Clauses}

Declarative clauses can be identified as clauses in which the structural element of subject occurs before the finite element of the clause. A declarative function to give the information and this is called statement. There are 256 declarative clauses. It is divided into 138 clauses on the WhatsApp's terms of service and 118 clauses on the WhatsApp's privacy notice.

From the table 4.2 , it can be seen that declarative clauses of terms of service is more dominant than declarative clauses in the privacy notice.

\section{Imperative Clauses}

Imperative clauses typically do not contain element of subject or finite, but imperative clauses consist of a predicator, any of the non-core participant of complement and adjuncts. Imperative mood is the only one types of mood in which have the Predicator (the verb). Imperative mood is the mood in which orders, commands, and requests are made.

In the table 4.2 it can be seen that there are 45 imperative clauses. It is divided into 27 clauses on WhatsApp's terms of service and 18 clauses on WhatsApp's privacy 
notice. An imperative clause is usually used for to make command or to ask someone to do something.

\section{Speech Functions}

In this research, the researcher found 337 clauses in the text. They are statement, questions and command. They are divided into 256 clauses into form of statement, 36 clauses into form of questions and 45 clauses in the form of command. It means that statement is more dominant than the other speech functions. The result can be seen from the table below:

\section{Table 3}

The Frequency of Speech Functions in the WhatsApp's

\begin{tabular}{|c|c|c|c|c|c|}
\hline \multirow{2}{*}{ Speech Functions } & \multicolumn{2}{|c|}{ Terms of Service } & \multicolumn{2}{|c|}{ Privacy Notices } & \multirow{2}{*}{ Total } \\
\cline { 2 - 5 } & Freq & $(\boldsymbol{\%})$ & Freq & $\mathbf{( \% )}$ & \\
\hline Statement & 139 & $45.87 \%$ & 123 & $40.59 \%$ & $86.46 \%$ \\
\hline Command & 23 & $7.59 \%$ & 18 & $5,94 \%$ & $13,53 \%$ \\
\hline Tot. Frequency & $\mathbf{1 6 2}$ & $\mathbf{4 8 . 9 5 \%}$ & $\mathbf{1 4 1}$ & $\mathbf{4 0 . 3 5 \%}$ & $\mathbf{1 0 0 \%}$ \\
\hline
\end{tabular}

From the table 3, it can be seen that there are two categories of speech function used in the terms of service, they are statement and command. In initiating the speech function, statements are $262(86,46 \%)$ \{divided in 139 in Terms of service and 123 in privacy notices , command are $41(13,53 \%)$ \{divided in 23 in the Terms of service and 18 privacy notices. It can be concluded that the Terms of service and privacy notices are giving information and ask the reader to do something to the users of WhatsApp's applications. 


\section{Discussion of Mood Types and Speech Functions in the WhatsApp's Terms of}

Service.

\section{Mood Types}

Mood types in the text are categorized into declarative, interrogative, imperative and exclamative. In this research, the writer only found declarative and imperative clauses in the Terms of Services.

\section{Declarative Clauses in the Terms of Services in Research.}

Declarative clauses are clauses found in the WhatsApp's Terms of Service Below are some examples taken from the data and the explanations.

\section{Excerpt 1}

This is an agreement between Research Inc., a California corporation ("Research"), the owner and operator of www.Research.com (the "Research Site”), the Research software, Including Research Messenger (collectively, including all content provided by Research through Research Messenger and the Research Site, the "Research Service", or the "Service"), and you ("you" or "You”), a user of the Service.

\begin{tabular}{|c|l|l|l|}
\hline This & is & & $\begin{array}{l}\text { an agreement between Research Inc., a California } \\
\text { corporation ("Research"), the owner and operator of } \\
\text { www.Research.com (the "Research Site"), the Research } \\
\text { software, Including Research Messenger (collectively, } \\
\text { including all content provided by Research through Research } \\
\text { Messenger and the Research Site, the "Research Service", or } \\
\text { the "Service"), and you ("you" or "You"), a user of the } \\
\text { Service. }\end{array}$ \\
\hline $\mathbf{S}$ & $\mathbf{T}$ & $\mathbf{P}$ & $\mathbf{C}$ \\
\hline & & $\mathbf{R}$
\end{tabular}

The declarative mood has the elements subject + finite. The clause (excerpt 1) from table shows it is categorized into declarative mood because the mood element in 
this clause is subject This followed by finite is. While the other clause in this sentence is complement and belongs to residue.

In addition, declarative mood can be identified from the position of the subject that proceeded finite appropriate with the declarative's formula. The function of this clause is the writer (companies) wants to give information for the reader (customer).

\section{Excerpt 2}

By using the service, you acknowledge and agree to these terms of service.

\begin{tabular}{|c|c|c|c|c|}
\hline $\begin{array}{l}\text { By using } \\
\text { the service }\end{array}$ & You & \multicolumn{2}{|l|}{$\begin{array}{l}\text { acknowledge } \\
\text { and agree }\end{array}$} & to these terms of service. \\
\hline Conj. Adj & S & $\mathbf{F}$ & $\mathbf{P}$ & \\
\hline & \multicolumn{3}{|c|}{$\mathbf{M}$} & \multicolumn{2}{|c|}{$\mathbf{R}$} \\
\hline
\end{tabular}

From the clause above is declarative mood. It can be seen by using pattern/ formula $=$ subject+finite (in Mood block). The clause above can be analyzed that the adverb By using the service as Mood adjunct, the subject of this clause is you, and the finite is acknowledge and agree. In addition, declarative mood can be identified from the position of the subject that precedes finite appropriate with the declarative's formula.

\section{Excerpt 3}

You may not use the Service

\begin{tabular}{|c|c|l|l|}
\hline You & $\begin{array}{l}\text { may } \\
\text { not }\end{array}$ & use & the service \\
\hline $\mathbf{S}$ & $\mathbf{F}$ & $\mathbf{P}$ & $\mathbf{C}$ \\
\hline
\end{tabular}


\begin{tabular}{|l|l|}
\hline $\mathbf{M}$ & $\mathbf{R}$ \\
\hline
\end{tabular}

The clause above shows that the statement is used in terms of service is categorized declarative. The form of this clause is Subject+Finite=Mood and complement as residue. The noun you in this clause as Subject, the verb (may not) include finite, and the service as complement of this clause.

In addition, declarative mood can be identified from the position of the subject that precedes finite appropriate with the declarative's formula. The clause above is use to convey information as the indicator of declarative mood, i.e. to give information to reader that terms of service should be paid attention more to the user of this application.

\section{Excerpt 4}

In addition, Research will not and cannot censor

\begin{tabular}{|c|c|c|c|c|}
\hline In addition & Rese & & Will not and cannot & censor \\
\hline Conj. adj & $\mathbf{S}$ & $\mathbf{F}$ & $\mathbf{P}$ & $\mathrm{C}$ \\
\hline $\mathbf{R}$ & $\mathbf{M}$ & & & \\
\hline
\end{tabular}

The clause (4) from table shows it is categorized into declarative mood since the mood element is subject + finite which the pronoun Research as Subject. The verb will not and cannot consider being finite. And in addition, as conjunctive adjunct and the verb censor is residue.

In addition, declarative mood can be identified from the position of the subject that precedes finite appropriate with the declarative's formula. The declarative of this clause has function to give information for the readers. 


\section{Excerpt 5}

that are not owned or controlled by Research.

\begin{tabular}{|c|c|c|c|}
\hline that & are not & owned or controlled & by Research \\
\hline Conj. adj & $\mathbf{F}$ & $\mathbf{P}$ & $\mathbf{C}$ \\
\hline & $\mathbf{M}$ & & \\
\hline
\end{tabular}

Those clauses above are all declarative. Declarative has structure are subject (we, people and I) followed by finite, while the finite as the part of verbal group can be followed by a predicator. It also can be seen as mood (subject + finite), finite verbal. These declarative clauses are to give functions as to make a statement, give information, give awarning, and give an advice and expressing emotion.

\section{Declarative Clauses in the Privacy Notices of Research.}

Below are the examples of declarative clauses in WhatsApp's Privacy Notices.

\section{Excerpt 6}

Research provides this Privacy Policy to help you make an informed decision about whether to use or continue using the Research Site, Research Software and/or the Research Service

\begin{tabular}{|c|c|c|l|}
\hline Research & provides & $\begin{array}{l}\text { this Privacy Policy to help you make an informed decision } \\
\text { about whether to use or continue using the Research Site, } \\
\text { Research Software and/or the Research Service }\end{array}$ \\
\hline S & $\mathbf{F}$ & $\mathbf{P}$ & $\mathbf{C}$ \\
\hline $\mathbf{M}$ & & $\mathbf{R}$ & \\
\hline
\end{tabular}

From the clause above is declarative mood. It can be seen by using pattern/ formula $=$ subject + finite $($ in Mood block). The clause above can be analyzed that the 
subject of this clause is Research, the verb provides as finite. This clause illustrates have Residue since complement is this Privacy Policy to help you make an informed decision about whether to use or continue using the Research Site, Research Software and/or the Research Service

In addition, declarative mood can be identified from the position of the subject that precedes finite appropriate with the declarative's formula. The function of declarative in the clause above is used by the writer to give information or statement to the reader (customer).

\section{Excerpt 7}

Research Inc. ("Research") recognizes

\begin{tabular}{|c|c|c|l|}
\hline $\begin{array}{l}\text { Research Inc. } \\
\text { ("Research") }\end{array}$ & \multicolumn{2}{|l|}{ recognizes } & $\begin{array}{l}\text { that its customers, visitors and users, want to know what's } \\
\text { up with privacy }\end{array}$ \\
\hline S & $\mathbf{F}$ & $\mathbf{P}$ & $\mathbf{C}$ \\
\hline $\mathbf{M}$ & & \multicolumn{2}{|c|}{$\mathbf{R}$} \\
\hline
\end{tabular}

The clause from table shows it is categorized into declarative mood since the mood element is subject + finite which the pronoun Research Inc. ("Research") as Subject. The verb is considered to be finite. And that its customers, visitors and users, want to know what's up with privacy is the complement and also residue of this clause.

In addition, declarative mood can be identified from the position of the subject that precedes finite appropriate with the declarative's formula. The declarative of this clause has function to give information for the readers. In this clause shows that it is to recognizes its customers, visitors and users with their privacy.

\section{Excerpt 8}


that its customers, visitors and users, want to know what's up with privacy

\begin{tabular}{|c|c|c|c|c|}
\hline that & $\begin{array}{l}\text { its customers } \\
\text { visitors and users }\end{array}$ & Wan & nov & what's up with privacy \\
\hline Conj. Adj & $\mathbf{S}$ & $\mathbf{F}$ & $\mathbf{P}$ & \multirow[t]{2}{*}{$\mathrm{C}$} \\
\hline & \multicolumn{2}{|l|}{$\mathbf{M}$} & & \\
\hline
\end{tabular}

\section{Excerpt 9}

If you do not agree to our practices, please do not use the Research Site, Research Software, or Research Service

\begin{tabular}{|c|c|c|c|c|}
\hline if & You do not & \multicolumn{2}{|c|}{ agree } & $\begin{array}{l}\text { to our practices, please do not use the } \\
\text { Research Site, Research Software,or } \\
\text { Research Service }\end{array}$ \\
\hline \multirow[t]{2}{*}{$\begin{array}{c}\text { Conj. } \\
\text { adj }\end{array}$} & $\mathbf{S}$ & $\mathbf{F}$ & $\mathbf{P}$ & $\mathrm{C}$ \\
\hline & \multicolumn{2}{|c|}{$\mathbf{M}$} & \multicolumn{2}{|r|}{$\mathbf{R}$} \\
\hline
\end{tabular}

From the clause above is declarative mood. It can be seen by using pattern/ formula $=$ subject+finite (in Mood block). The clause above can be analyzed that the subject of this clause is you, the verb agrees as finite. This slogan illustrate have Residue since complement is to our practices, please do not use the Research Site, Research Software, or Research Service

\section{Excerpt 10}

This Privacy Policy is incorporated into and is subject to the Research Terms of Service

\begin{tabular}{|c|l|l|l|l|}
\hline this & Privacy policy & \multicolumn{2}{|l|}{ is } & \multicolumn{2}{l|}{$\begin{array}{l}\text { into and is subject to the Research } \\
\text { Term } \text { of Service }\end{array}$} \\
\hline $\begin{array}{c}\text { Conj. } \\
\text { Adj }\end{array}$ & S & F & P & Circ. adj \\
\hline
\end{tabular}




\begin{tabular}{|l|l|}
\hline $\mathbf{M}$ & $\mathbf{R}$ \\
\hline
\end{tabular}

Those clauses above are all declarative. Declarative has structure are subject (we, people and I) followed by finite, while the finite as the part of verbal group can be followed by a predicator. It also can be seen as mood (subject + finite), finite verbal. These declarative clauses are to give functions as to make a statement, give information, give awarning, and give an advice and expressing emotion.

The other clauses are identified as declaratives can be seen in appendixes.

\section{Imperative Clauses}

There are 27 clauses found in the term of services and 18 clauses in privacy notices in Research. The mood element of imperative mood always be a predicator. Imperative Mood may be used to convey a command. Thus the use of imperatives can indicate that the writer of the fast food restaurant clauses is in a position of greater power than the readers or the customers. Imperative sentences express directives, such as orders, instructions, requests, invitation, etc. Below are the explanations.

\section{Excerpt 10}

Edit the content of any third-party site

\begin{tabular}{|c|c|}
\hline Edit & the content of any third-party site \\
\hline $\mathbf{P}$ & $\mathbf{C}$ \\
\hline \multicolumn{2}{|c|}{ Residue } \\
\hline
\end{tabular}

The clause from table shows that the clause used in terms of services is categorized into imperative mood. This clause illustrate has Residue since the predicator is Edit and the content of any third-party site as complement of this clause. 
In addition, indicator of imperative mood could be no mood (subject+finite) they consist of predicators and complements (residue). The function of clause above is used to make command, i.e. to make command reader (customer).

\section{Excerpt 11}

Subject to your compliance with these Terms of Service

\begin{tabular}{|c|c|}
\hline Subject & to your compliance with these Terms of Service \\
\hline $\mathbf{P}$ & $\mathbf{C}$ \\
\hline \multicolumn{2}{|c|}{ Residue } \\
\hline
\end{tabular}

From clause in table shows that it is used in Terms of service is categorized into imperative mood. This clause illustrates has Residue since the predicator is Buy and have, while fresh as complement of this clause.

In addition, indicator of imperative mood could be no mood (subject+finite) they consist of predicators and complements (residue). The function of clause above is used to make command, i.e. to ask the reader (user) to do something deals with its instruction in terms of service.

\section{Excerpt 12}

Please note that any Status Submissions or other content posted at the direction or discretion of users of the Research Service becomes published content and is not considered personally identifiable information subject to this Privacy Policy.

\begin{tabular}{|c|l|}
\hline Please note & $\begin{array}{l}\text { that any Status Submissions or other content posted at the } \\
\text { direction or discretion of users of the Research Service } \\
\text { becomes published content and is not considered personally } \\
\text { identifiable information subject to this Privacy Policy. }\end{array}$ \\
\hline $\mathbf{P}$ & \multicolumn{1}{c}{$\mathbf{C}$} \\
\hline
\end{tabular}




\section{Excerpt 13}

Use your mobile phone number (or email address, if provided) without further consent for non-marketing or administrative purposes (such as notifying you of Major Research Site.

\begin{tabular}{|c|l|}
\hline Use & $\begin{array}{l}\text { your mobile phone number (or email address, if provided) without } \\
\text { further consent for non-marketing or administrative purposes (such as } \\
\text { notifying you of Major Research Site. }\end{array}$ \\
\hline $\mathbf{P}$ & $\mathbf{C}$ \\
\hline \multicolumn{2}{|c|}{ Residue } \\
\hline
\end{tabular}

Indicator of imperative mood could be no mood (subject+finite) they consist of

predicators and complements (residue). The function of clause above is use to make command, i.e. to the reader (customer) to do something deals with its order in privacy notice of Research. The other clauses of imperative mood can be seen from the appendixes.

\section{Speech Function}

There are many kinds of speech functions theory such as Janet Holmes, Kinneavy, Michael Halliday, Jacobson, and Wardaugh. But to analyze the speech functions through the Terms of service in Research the writer uses Gerot and Wignell theory (1994). There are options of speech functions ${ }^{1}$ : they are offer, statement, question and command.

\section{Statement}

\footnotetext{
${ }^{1}$ Gerot, Linda and Wignell, Peter. 1994. Making Sense of Functional Grammar, First Edition. Queensland. Australia: Antipodean Educational Enterprises. P.22.
} 
Statement is as speech function that has purpose to give information. This speech function is used to express the speakers' ideas and to receive information.

\section{Statement clauses of Terms of Service}

Below are the explanations of clauses in Terms of service based on speech functions.

\section{Excerpt 14}

This is an agreement between Research Inc., a California corporation ("Research"), the owner and operator of www.Research.com (the "Research Site"), the Research software, Including Research Messenger (collectively, including all content provided by Research through Research Messenger and the Research Site, the "Research Service", or the "Service"), and you ("you" or "You"), a user of the Service.

The clause above expresses the idea of the author. It gives the information to the reader about these terms of service. It has purpose to reader that WhatsApp is owned in California corporation ("Research"), the owner and operator of www.Research.com. The author makes sure about the information given.

\section{Excerpt 15}

By using the service, you acknowledge and agree to these terms of service.

The clause above is used in statement. The writer has purpose to give information that by using this statement, the reader will understand that the user of Research application should acknowledge and agree all terms of service. 


\section{Excerpt 16}

If you choose to not agree with any of these terms, You may not use the Service

This clause is statement. It is because the writer has purpose to give information to the reader. If the user of Research application will use it, the user should agree or disagree. If you disagree with this statement, the user may not use the service of Research application.

\section{Excerpt 17}

Research provides this Privacy Policy to help you make an informed decision about whether to use or continue using the Research Site, Research Software and/or the Research Service.

\section{Excerpt 18}

This Privacy Policy is incorporated into and is subject to the Research Terms of Service

\section{Excerpt 19}

Your use of the Research Site, Research Software and the Research Service and any personal information you provide on the Research Site or Research Service remains subject to the terms of this Privacy Policy and our Terms of Service

All clauses above are statement.it can be known that those sentences are statement from the formula. It is also recognized the function of speech in which the writer has purposes to give information, ideas or fact which the writer realizes by giving statements. In excerpt 17 until 19 have function that the writer gives information about privacy notices in using Research application. The Research Corporation does not have any responsibilities about user's privacy. Other clauses can be seen in appendixes. 


\section{Command}

The speaker demands the hearer some goods and services and the hearer are thereby invited to give that service or provide the goods. Example: "see the notification tab of setting for more". In the text, the researcher found 27 clauses in the Terms of Service and 18 clauses in Privacy Notices in Research. Below are some examples of command as function of speech.

(1). Edit the content of any third-party site

(2). Please delete your account, uninstall the Research mobile application and discontinue use of the Research Service

In data (1) and data (2) it can be seen that the writer gives command to the reader that the reader should edit the content. The formulas are in the pattern of imperatives.

(3). Subject to your compliance with these Terms of Service

(4). charge others for use

(5). access to the Service, or in any other manner inconsistent with these Terms of Service

(6). modify any part of the Service

(7). address book on your mobile device to find

(8). keep track of mobile phone numbers of other users of the Service.

(9). address book for mobile phone numbers in order to provide and use the Service

In data 6 to 9 are in the form of command. It can be seen from the writer purpose. The function of speech is to ask the reader to do something. As in data 6 that the writer asks the reader to modify any part of services in Research application. Modify is as subjective and any part of the service is complementing. It has already known for the purpose when the reader read the text on the Terms of Service.

(10). So, don't submit or post status messages or profile photos

(11). Don't submit it as a Status Submission to the Service 
In data 9 and 10 shows other form of command. The writer has purpose to reader not to do what the writer's purpose. The utterances have function to forbid reader to do something. From the patterns, it can be seen that the word Don't is negative command. Forbidden are also kinds of command as speech function realization.

\section{Initiating Congruent and Incongruent Speech Function and Mood Types.}

\section{Statement}

The typical mood type of congruent speech function for statement is declarative clauses. Below are the examples of concurrent statements.

\begin{tabular}{|l|l|l|l|}
\hline No & \multicolumn{1}{|c|}{ Clause } & Mood types & Speech functions \\
\hline 1 & $\begin{array}{l}\text { This is an agreement between } \\
\text { Research Inc., a California } \\
\text { corporation ("Research"), the owner } \\
\text { and operator of www. Research.com } \\
\text { (the "Research Site"), the Research } \\
\text { software, Including Research } \\
\text { Messenger (collectively, including all } \\
\text { content provided by Research through } \\
\text { Research Messenger and the } \\
\text { Research Site, the "Research } \\
\text { Service", or the "Service"), and you } \\
\text { "'you" or "You"), a user of the } \\
\text { Service. }\end{array}$ & Declarative \\
\hline 2 & $\begin{array}{l}\text { By using the service, you } \\
\text { acknowledge and agree to these terms } \\
\text { of service }\end{array}$ & Statement \\
\hline 3 & $\begin{array}{l}\text { Research provides this Privacy Policy } \\
\text { to help you make an informed } \\
\text { decision about whether to use or } \\
\text { continue using the Research Site, } \\
\text { Research Software and/or the }\end{array}$ & Declarative & Statement \\
\hline
\end{tabular}




\begin{tabular}{|l|l|l|l|}
\hline & Research Service. & & \\
\hline 4 & Which can be found & Declarative & Statement \\
\hline 5 & $\begin{array}{l}\text { These Terms of Service apply to all } \\
\text { users of the Research Service }\end{array}$ & Declarative \\
\hline 6 & $\begin{array}{l}\text { By using the Service, you expressly } \\
\text { acknowledge and agree }\end{array}$ & Declarative & Statement \\
\hline 7 & $\begin{array}{l}\text { This Privacy Policy is incorporated } \\
\text { into and is subject to the Research } \\
\text { Terms of Service }\end{array}$ & Declarative & Statement \\
\hline
\end{tabular}

From the list above, it can be seen that statement as speech function in the text of Terms of Service and Privacy Notices are congruent, because the utterances have the same typical in mood types in the clauses that is declarative. It means that the mood types of declarative show the congruency of statement as initiating speech function.

\section{Command}

Below are the examples of congruency mood types and speech function found in the text.

\begin{tabular}{|c|l|l|l|}
\hline No & \multicolumn{1}{|c|}{ Clause } & Mood types & Speech functions \\
\hline 1 & Edit the content of any third-party site & Imperative & Command \\
\hline 2 & $\begin{array}{l}\text { Subject to your compliance with these } \\
\text { Terms of Service }\end{array}$ & Imperative & Command \\
\hline 3 & $\begin{array}{l}\text { access to the Service, or in any other } \\
\text { manner inconsistent with these Terms } \\
\text { of Service; }\end{array}$ & Imperative & Command \\
\hline 4 & $\begin{array}{l}\text { modify any part of the Service } \\
\text { address book on your mobile device } \\
\text { to find }\end{array}$ & Imperative & Command \\
\hline 6 & $\begin{array}{l}\text { keep track of mobile phone numbers } \\
\text { of other users of the Service }\end{array}$ & Imperative \\
\hline 7 & $\begin{array}{l}\text { address book for mobile phone } \\
\text { numbers in order to provide and use } \\
\text { the Service }\end{array}$ & Imperative & Command \\
\hline
\end{tabular}




\begin{tabular}{|c|c|c|c|}
\hline 8 & $\begin{array}{l}\text { Submit material that is copyrighted, } \\
\text { protected by trade secret or otherwise } \\
\text { subject to third party proprietary } \\
\text { rights, including privacy and publicity } \\
\text { rights }\end{array}$ & Imperative & Command \\
\hline 9 & $\begin{array}{l}\text { Publish falsehoods or } \\
\text { misrepresentations that could damage } \\
\text { Research or any third party }\end{array}$ & Imperative & Command \\
\hline 10 & $\begin{array}{l}\text { Submit material that is unlawful, } \\
\text { obscene, defamatory, libelous, } \\
\text { threatening, harassing, hateful, } \\
\text { racially or ethnically offensive }\end{array}$ & Imperative & Command \\
\hline 11 & $\begin{array}{l}\text { Post advertisements or solicitations of } \\
\text { business }\end{array}$ & Imperative & Command \\
\hline 12 & $\begin{array}{l}\text { Send or store material containing } \\
\text { software viruses, worms, Trojan } \\
\text { horses or other harmful computer } \\
\text { code, files, scripts, agents or } \\
\text { programs }\end{array}$ & Imperative & Command \\
\hline
\end{tabular}

From the list above, it can be known that command as speech function in the text of Terms of Service and Privacy Notices are congruent. It is because they have type of mood as imperative. It means that mood types of imperative show the congruency of command as speech function initiating. The researcher did not find any incongruent clauses both in Terms of service and Privacy Notices.

\section{Conclusion}

1. The researcher found 336 clauses. The clauses are divided into 186 clauses on WhatsApp's Term and Services and 150 clauses found in WhatsApp's Privacy Notices. It can be seen that there are two types of mood in the text of WhatsApp's Terms of Service and Privacy Notice. They are declarative mood 
type, imperative mood type. In the table, there are 262 declarative clauses (139 clauses or $45,87 \%$ in Terms of Service and 123 clauses or $40,59 \%$ in Privacy Notices) in text, 41 imperative clauses or (23 clauses or $7.59 \%$ in Terms of Service and 18 clauses or 5, 94\% in Privacy Notices). It means that declarative clauses are the more dominant than imperative clauses in the text of WhatsApp's Terms of Service.

2. The speech functions found in the text of Terms of Service in Research are two categories of speech function used in the terms of service, they are statement and command. In initiating the speech function, statements are $262(86,46 \%)$ \{divided in 139 in Terms of service and 123 in privacy notices\}, command are $41(13,53 \%)$ d divided in 23 in the Terms of service and 18 privacy notices. It can be concluded that the Terms of service and privacy notices are giving information and ask the reader to do something to the users of WhatApps's applications. In the text, forms of mood types and speech functions have the same purposes. The writer only uses imperative and declarative and also imperative and command. They used negative clauses but the clauses are not included in the form of mood types and speech functions.

\footnotetext{
About the writer

Mohammad Muhyidin obtained his master's degree from Islamic University of Malang and is currently a lecturer at the State Institute for Islamic Studies (IAIN) Kediri. He had previously taught at other institutions such as Kadiri Islamic University (Uniska),
} 
University of Kadiri (Unik), and MTsN 2 Kediri. He has taught various areas in ELT including the language skills (Speaking, Listening, Writing), English Phonology, English Morphology, and IELTS.

\section{References}

Eggins \& Suzanne. (1994). An Introduction to Systemic Functional Linguistics. London: Pinter Publisher Ltd.

Fauzi \& Siska. (2013). Mood and Speech Function Realizations of Right and Responsibilities in WhatsApp's Terms of Service. (Unpublished Theses). Faculty of Humanities. Dian Nuswantoro University, Semarang.

Gerot, Linda and Wignell \& Peter. (1994). Making Sense of Functional Grammar. $\left(1^{\text {st }}\right.$ ed.). Queensland. Australia: Antipodean Educational Enterprises.

Halliday. M. A. K. (1985). An Introduction to Functional Grammar. London: Edward Arnold.

Halliday \& Matthiessen. (2004). An Introduction to Functional Grammar. ( ${ }^{\text {rd }}$ ed.). London: Edward Arnold.

Matthew B. M \& Hubberman. (1984). Qualitative Data Analysis. Deverly Hills, California: SAGE Publications.

Rosida. W. (2015). "The Analysis of Speech Functions through the Dialogue in Braveheart Movie Script". (Unpublished Theses). Tarbiyah, English Department: The State College for Islamic Studies of Kediri

Yeibo. (2011). A Discourse-Stylistic Analysis of Mood Structures in Selected Poems of J.P. Clark-Bekederemo. International Journal of Humanities and Social Science.Vol. 1, No.16. 